JURNAL HUMANIORA

TEKNOLOGI

Vol. 1 No.1 ; Oktober 2015

\title{
STRATEGI PENGELOLAAN ANGGARAN BIAYA PENDIDIKAN BERBASIS KINERJA DI SEKOLAH MENENGAH ATAS NEGERI KABUPATEN TANAH LAUT
}

\author{
MUFRIDA ZEIN \\ Dosen MKDU di Politeknik Negeri Tanah Laut \\ Jl. A. Yani Km. 6 Ds. Panggung Kec. Pelaihari Kab. Tanah Laut, Kalimantan Selatan
}

\begin{abstract}
Abstrak
Telah dilakukan penelitian tentang strategi pengelolaan anggaran biaya pendidikan berbasis kinerja (BPBK) di SMAN 1 Pelaihari, menggunakan pendekatan kualitatif. Penelitian ini bertujuan untuk menganalisis implementasi anggaran BPBK, menemukan dan mendiskripsikan strategi perencanaan, pengorganisasian, pelaksanaan, pengawasan dan sistem pelaporan serta faktor-faktor strategis pendukung dan penghambat pengelolaan anggaran $B P B K$.

Hasil penelitian ini menunjukkan bahwa Biaya Pendidikan persiswa/tahun di SMAN 1 Pelaihari 2.250.000,-. Jika mengacu standar anggaran nasional sebesar Rp. 3.000.000,/siswa/tahun, SMA Negeri 1 Pelaihari belum memenuhi standar. Penerapan anggaran BPBK belum bisa berjalan optimal karena belum terpenuhinya beberapa persyaratan dan kelengkapan teknis, oleh karenanya diperlukan pertama, kepala sekolah ditetapkan sebagai KPA dan bendahara pembantu menjadi bendahara pengeluaran. Kedua dokumen RENSTRA, RENJA dan IKU wajib dimiliki sekolah, sehingga LAKIP dapat dilaksanakan. ketiga SIMDA harus mengakomodir program kreatif dan inovatif untuk tercapainya visi dan misi sekolah.

Strategi perencanaan, pengorganisasian, pelaksanaan, pengawasan dan sistem pelaporan anggaran dilaksanakan berdasarkan pendekatan partisipatif melibatkan seluruh pihak, baik komite sekolah maupun guru-guru, untuk mendorong keterbukaan sehingga memacu semangat guru untuk realisasi program. Keterlibatan ini dilaksanakan hingga proses pelaporan agar terjadi check and balance. Keluhan oleh komite sekolah didapati pada SMA Negeri 1 Pelaihari karena tidak terlibat dalam pengawasan anggaran. Faktorfaktor pendukung pengelolaan anggaran berbasis kinerja adalah tersedianya visi dan misi serta dukungan pendanaan cukup besar. Hambatan pelaksanaan ABK yaitu Jargon politik "pendidikan gratis" kepala daerah sehingga sekolah tidak dapat leluasa mendapat dukungan dana melalui masyarakat.
\end{abstract}

Kata kunci: Strategi pengelolaan anggaran, pendidikan berbasis kinerja, LAKIP 


\section{PENDAHULUAN}

\section{Latar Belakang}

Perubahan sistem sentralisasi menjadi desentralisasi dalam urusan pemerintah merupakan momentum reformasi sistem pemerintahan. Sektor pendidikan ikut mengalami perubahan sistem, dimana sebelum otonomi daerah, pemerintah daerah hanya bertanggung jawab pada pengelolaan pendidikan di tingkat SD sedangkan SMP dan SMA menjadi tanggung jawab pemerintah pusat. Setelah diterapkan otonomi daerah di sektor pendidikan mengalami perubahan yakni seluruh pengelolaan sekolah dari SD hingga SMA menjadi tanggung jawab pemerintah kabupaten yang dibiayai lewat APBD. Permasalahan yang dihadapi adalah antara dinas kabupaten/kota dengan Dinas Pendidikan provinsi yang merupakan perpanjangan tangan pemerintah pusat tidak ada hubungan hierarkis, dan implikasinya adalah setiap program di tingkat sekolah harus dilakukan melalui koordinasi dengan Pemkab khususnya Dinas Pendidikan kabupaten/kota (Priyono, 2007:66). Oleh karena itu, kepala SMA yang berperan menjadi manajer, administrator dan advisor di dalam sebuah sekolah harus memiliki kemampuan kepemimpinan yang baik, dalam mengelola sebuah lembaga pendidikan pada jenjang menengah atas agar tercapai visi, misi dan tujuan yang telah ditetapkan oleh sekolah.

Undang-Undang Nomor 20 Tahun 2003 tentang Sistem Pendidikan Nasional merupakan respon terhadap tuntutan reformasi di bidang pendidikan. Sejalan dengan prinsip desentralisasi, Undang-Undang Nomor 32 Tahun 2004 dan Peraturan Pemerintah Nomor 38 Tahun 2007 mengatur penyelenggaraan dan pengelolaan pendidikan yang menjadi kewenangan Pemerintah, pemerintah provinsi, dan pemerintah kabupaten/kota. Undangundang Sisdiknas mengamanatkan bahwa sedikitnya pemerintah pusat dan daerah (Provinsi/Kabupaten/Kota) wajib menganggarkan biaya penyelenggaraan pendidikan minimal 20\% dari APBN dan APBD diluar gaji pendidik dan biaya pendidikan kedinasan. Besarnya APBN dan APBD di sektor pendidikan dan adanya tuntutan good coorporate governance, mendorong adanya reformasi sistem penganggaran dengan penerapan penganggaran berbasis kinerja di Kementerian Pendidikan dan Kebudayaan dengan tiga prinsip utamanya yang berlaku secara universal yaitu profesional, transparan, dan akuntabilitas.

Penganggaran berbasis kinerja (performance based budget) merupakan hal yang baru dalam dunia pendidikan karena pusat perhatian diarahkan pada pencapaian hasil (outcome) 
dari pengalokasian biaya yang didasarkan pada kegiatan atau program kerja yang dilaksanakan secara ekonomis, efektif dan efisien. Sistem anggaran ini berorientasi pada output organisasi yang berkaitan sangat erat dengan visi, misi dan rencana strategis organisasi (Bastian 2001:102). Oleh sebab itu, dalam penyusunan anggaran berbasis kinerja seluruh pihak hingga pegawai ditingkat bawah dapat mengetahui dan memahami tugas dan strategi yang akan dicapai untuk mencapai tujuan organisasi. Melalui penerapan anggaran berbasis kinerja, lembaga pendidikan dituntut untuk membuat standar kinerja pada setiap anggaran kegiatan, sehingga jelas kegiatan apa yang akan dilakukan, berapa biaya yang dibutuhkan, dan apa hasil yang akan diperoleh. Dengan demikian, diharapkan penyusunan dan pengalokasian anggaran dapat lebih disesuaikan dengan skala prioritas dan preferensi lembaga pendidikan yang bersangkutan, dengan memperhatikan prinsip ekonomis, efisiensi dan efektivitas.

Adanya perbedaan tahun pelaksanaan angggaran ini seringkali menjadi permasalahan di sekolah, karena kebutuhan dasar dalam operasional sekolah haruslah pada bulan januari awal tahun itu berjalan penyediaan dana untuk pembiayaan yang mesti dikeluarkan. Masalah yang cukup serius adalah belum mencukupinya anggaran biaya pendidikan pada satuan pendidikan jenjang SMA. Penganggaran yang dilaksanakan pemerintah bersifat (berhorison) 1 (satu) tahun, padahal sekolah persemester. Hal yang sangat sulit bagi sekolah untuk mengikuti sistem keuangan yang berbasis kinerja ini adalah melalui mekanisme sistem manajemen keuangan daerah SIMDA, yang notebenenya adalah tidak semua kode kegiatan dan kode rekening itu sesuai dengaan kehendak sekolah, karena selama ini pembuatan kode kegiatan dan kode rekening tersebut adalah berdasarkan yang dibutuhkan dalam kementerian dalam negeri (KEMENDAGRI), yang kurang memperhatikan pada kegiatan di satuan pendidikan SMA.

Perbedaan waktu penganggaran dana di sektor pendidikan oleh pemerintah daerah dan perbedaan karakteristik gaya kepemimpinan kepala sekolah yang dituntut untuk tepat dan kreatif menentukan program-program sebagai upaya untuk meningkatkan produktifitas kinerja pendidikan sehingga mendorong peneliti untuk melakukan penelitian dengan rancangan multi kasus tentang strategi pengelolaan anggaran biaya pendidikan berbasis kinerja pada SMA Negeri 1 Pelaihari, SMA Negeri 1 Bati-Bati, dan SMA Negeri 1 Jorong di kabupaten Tanah Laut.

Penelitian ini bertujuan untuk menganalisis mekanisme anggaran biaya, struktur anggaran biaya pendidikan di SMA Negeri 1 Pelaihari, SMA Negeri 1 Bati-Bati, dan SMA Negeri 1 Jorong di kabupaten Tanah Laut SMA. Selanjutnya untuk menemukan dan 
mendiskripsikan strategi perencanaan, pelaksanaan, pertanggungjawaban dan pelaporan kegiatan anggaran berbasis kinerja serta menemukan dan mendiskripsikan faktor-faktor apa saja yang mendukung dan menghambat kepemimpinan kepala sekolah dalam pengelolaan biaya pendidikan berbasis kinerja di sekolah, sehingga ditemukan model pengelolaan anggaran biaya pendidikan berbasis kinerja di SMAN 1 Pelaihari SMA Negeri 1 Bati-Bati, dan SMA Negeri 1 Jorong di kabupaten Tanah Laut.

\section{METODE PENELITIAN}

\section{A. Pendekatan Rancangan Penelitian}

Penelitian ini menggunakan pendekatan analisis deskripsi kualitatif (cualitative research approach) dengan tiga tahap penelitian yang ditempuh yaitu: (1) studi persiapan/orientasi, (2) studi eksplorasi umum, dan (3) studi eksplorasi terfokus, dimana peneliti terlibat secara penuh untuk memahami interaksi fenomena alami oleh subjek penelitian seperti perilaku, persepsi, motovasi dan tindakan secara menyeluruh dan deskriptif dengan memanfaatkan berbagai metode yang alamiah (Moleong, 2006:94). Penelitian kualitatif bermaksud untuk memahami fenomena tentang apa yang alami Untuk dapat memahami makna peristiwa dan interaksi orang, digunakan orientasi teoritik atau perspektif teoritik dengan pendekatan fenomenologis (phenonmenological approach). Peneliti berusaha memahami subjek dari sudut pandang subjek itu sendiri, dengan tidak mengabaikan penafsiran, dengan membuat skema konseptual.

Pendekatan kualitatif dalam penelitian ini bertujuan untuk mendiskripsikan pemahaman atas fenomena penganggaran dengan berfokus bagaimana proses penyusunan anggaran untuk mencapai tujuan dan sasaran melalui visi dan misi sebagai tolok ukur kerja.

\section{B. Data dan Sumber Data}

Data yang dikumpulkan melalui penelitian ini adalah data yang sesuai dengan fokus penelitian, yaitu tentang strategi kepala sekolah dalam pengelolaan biaya pendidikan berbasis kinerja di Kabupaten Tanah Laut, Kabupaten Banjar, dan Kota Banjarbaru yaitu SMAN 1 Pelaihari, SMAN 1 Bati-Bati dan SMAN 1 Jorong. Jenis data dalam penelitian ini dapat dibedakan menjadi dua yaitu data primer dan data sekunder. Data primer diperoleh dalam bentuk verbal atau kata-kata atau ucapan lisan berkaitan dengan peran kepemimpinan kepala sekolah. 


\section{Prosedur Pengumpulan Data}

Untuk memperoleh data secara holistik dan integratif, serta memperhatikan relevansi data dengan fokus dan tujuan, maka dalam pengumpulan data penelitian ini digunakan tiga teknik, yaitu: (1) wawancara mendalam (in depth interview); (2) observasi partisipan (participant observation); dan (3) studi dokumentasi (study of documents). Tiga teknik tersebut merupakan tiga teknik dasar dalam penelitian kualitatif yang disepakati oleh sebagian besar penulis yaitu wawancara mendalam, observasi partisipan dan studi dokumentasi. (Nasution, 1998:21).

\section{Analisis Data}

Analisis data merupakan proses mencari dan mengatur secara sistematis transkrip wawancara, catatan lapangan, dan bahan-bahan lain yang telah dihimpun oleh peneliti. Kegiatan analisis ini dilakukan dengan menelaah data, menata, membagi menjadi satuansataun yang dapat dikelola, mensintesis, mencari pola, menemukan apa yang bermakna, dan apa yang diteliti dan dilaporkan ecara sistematis (Bogdan \& Biklen, 1982:101). Data itu sendiri terdiri dari deskripsi-deskripsi yang rinci mengenai situasi, peristiwa, orang, interaksi, dan perilaku. Dengan kata lain, data merupakan deskripsi dari pernyataan-pernyataan seseorang tentang perspektif, pengalaman atau sesuatu hal, sikap, keyakinan, dan pikirannya serta petikan-petikan isi dokumen yang berkaitan dengan suatu program. dalam menganalisis data dilakukan dua tahap, yaitu: (1) analisis data kasus individu (individual case), dan (2) analisis data lintas kasus (cross case analysis), (Yin, 1987:21).

\section{E. Pengecekan Keabsahan Data}

Pengecekan kredibilitas atau derajat kepercayaan data perlu dilakukan untuk membuktikan apakah yang diamatai oleh peneliti benar-benar telah sesuai dengan apa yang sesungguhnya terjadi secara wajar di lapangan. Derajad kepercayaan data (kesahihan data) dalam penelitian kualitatif digunakan untuk memenuhi kriteria (nilai) kebenaran yang bersifat emic, baik bagi pembaca maupun bagi subjek yang diteliti. Pelaksanaan pengecekan keabsahan data didasarkan pada empat kriteria yaitu derajat kepercayaan (credibility), keteralihan (transferability), kebergantugan (dependability), dan kepastian (confirmability) (Moleong, 2006:76). 


\section{HASIL DAN PEMBAHASAN}

\section{A. Mekanisme Anggaran Biaya Pendidikan}

Sebagaimana diketahui bahwa dalam temuan di tiga sekolah yang menjadi objek penelitian ini mekanisme penganggaran biaya pendidikan terdapat perbedaan dan juga ada persamaan. Jika dipandang secara pembahasan teoritik, dapat disampaikan sebagai berikut; Pertama, dari sumber anggaran, maka ditiga objek penelitian terdiri dari dua sumber, yaitu dari pemerintah pusat dan daerah, (BOS-SM dan BOMM), dan dari komite sekolah dari orang tua. Kedua; dilihat dari sistem mekanis penganggarannya, menggunakan Line Item Budgeting, yaitu sistem penganggaran pendidikan yang berorientasi kepada jenis barang yang diperlukan, ini ditujukan kepala anggaran yang bersumber dari komite sekolah, dan program budgeting dan Planning Programming dan Budgeting System, sistem penganggaran pendidikan yang berorientasi selain jenis barang yang diperlukan, juga memprogramkan pada kebutuhan jangka waktu yang lebih lama, dan selain itu dikaitkan dengan orientasi mutu keluaran (Matin; 2014:55), hal ini ditujukan kepada anggaran yang diberikan pemerintah daerah melalui BOMM untuk SMA 1 Pelaihari, dan R-Wajar 12 tahun. Ketiga; melihat dari jenis sumber anggaran, maka pengganggaran dibuat berdasarkan penyusunan kebutuhan fisik dan non fisik, yaitu anggaran rutin (recurrent budget) seperti yang tertuang dalam RKA/DPA, dan anggaran pembangunan (development budget), (Fatah; 2012:52) yang dalam hal ini tidak diungkapkan dalam hasil temuan penelitian. Namun dalam analisis anggaran satuan biaya pendidikan, dan sumber-sumber biaya pendidikan hanya disebutkan pada tiga Belanja Pegawai, belanja barang dan jasa, serta belanja modal, hal ini dapat dilihat pada DPA Dinas Pendidikan, namun di laporan BOS-SM tidak ditemukan.

Mekanisme penganggaran dilaksanakan melalui rapat sekolah, kemudian bersama komite, dibawa dalam rapat yang lebih besar yaitu rapat pleno, yang membahas rancangan anggaran biaya pendidikan bersama dengan seluruh anggota komite sekolah, hal ini tampaknya hanya pada anggaran yang berasal dari komite sekolah, sedangkan pada anggaran yang bersumber dari pemerintah pusat maupun dari daerah, yang memiliki program keunggulan sendiri ditiap-tiap kabupaten/kotan, dengan visi dan misi yang berbeda tidak terbahas oleh sekolah secara transpara, tampaknya pihak sekolah hanya pengusul dari jumlah kebutuhan siswa dan berapa banyaknya jumlah siswa yang ditampung, karena anggaran BOS-SM dan yang lainnya dihitung dari banyaknya siswa.

Setelah otonomi daerah, penganggaran pembangunan sepenuhnya diserahkah kepada Dinas Pendidikan atau kepada PU atau Cipta Karya/Sarana Prasarana, sehingga sekolah tidak 
mendapatkan kesempatan untuk memberikan pemikiran dan kebutuhan yang sesuai dengan visi dan kreativitas dari pihak sekolah namun hanya sebagai penerima hasil dari biaya anggaran pembangunan. Dalam hal ini, peranan kepala sekolah sebagai pimpinan yang memiliki kemampuan manajemen strategi yang berkaitan dengan pelaksanaan gagasan, perencanaan dan ekskusi sebuah kegiatan organisasi sekolah dalam jangka waktu yang panjang menjadi terabaikan (Amrullah 2014:5). Oleh sebab itu, perbaikan tatanan penganggaran semestinya mengalami reformasi, yakni harus dikaitkan dengan visi dan misi serta berikan kesempatan melaksanakannya kegiatan tersebut.

Berkenaan dengan mekanisme pengganggaran dari bentuknya, sistem line item budgeting (LIB) atau penganggaran berbasis kinerja. Kedua sistem ini dilaksanakan dan penganggaran untuk ketiga sekolah ini, yaitu untuk LIB lebih kepada anggaran dari komite sekolah, sedangkan ABK yang menegaskan bahwa rencana kerja dan anggaran yang disusun menggunakan tiga pendekatan, yaitu anggaran terpadu, kerangka pengeluaran jangka menengah dan penganggaran berbasis kinerja (performance budget). Hal ini sesuai dengan model yang dikehendaki, tanpa melihat dari sumber dan proses dan alur penganggaran bersama komite, yang lebih kepada bentuk LIB, sedangkan pada aspek mutu, keluaran dan hasil diabaikan.

Mekanisme pengannggaran di tiga objek penelitian ini melalui dari arus bawah (bottom up) dengan anggaran komite sekolah, sedangkan pengganggaran dari atas (top-down) dari sumber pemerintah. Terkait format penganggaran lebih mendekati pada Rencana Kegiatan Anggaran yang dibuat pemerintah daerah (SIMDA) Permendagri, daripada keluaran RKA kementerian atau Dirjen Anggaran Kementerian Keuangan (PMK). hanya saja tidak terlalu memperhatikan dari segi, input, output dan outcomes, serta sasaran kinerja yang ditetapkan dalam perencanaan. Disamping itu penekanan pada mekanisme penganggaran di tiga objek penelitian ini, bersandar pada sumber-sumber anggaran biaya pendidikan yang didapatkan hanya ada pada dua sumber, yaitu pemerintah dan komite sekolah (orang tua peserta didik), sedangkan hibah, usaha dan pihak ketiga lainnya tidak ada. Hal ini secara keseluruhan karena adanya slogan pendidikan gratis, melalui isu yang disebarkan kemasyarakat, sebagai ekses dari pemilukada, sehingga keyakinan masyarakat bahwa pendidikan itu benar-benar ditanggung sepenuhnya oleh pemerintah.

Di tiga SMAN 1 ini berada di daerah industri dan perusahaan yang potensial untuk memberikan dana pendidikan dari tanggung jawab sosial dari perusahaan (Corporate Social Responsibility), namun potensi ini belum tergali. Kenyataan yang nampak saat ini adalah perusahaan lebih mengutamakan penyaluran dana CSR untuk lembaga pendidikan 
pendidikan anak usia dini (PAUD), dan sekolah dasar (SD). Namun karena kepentingan dan masih besar tanggung jawab para orang tua, sehingga sumbangan dari pihak komite sekolah cukup besar, Karena itu dalam sumber utama dari komiah dite sekolah lebih mudah diakomodir anggaran yang diajukan sekolah kepada komite sekolah.

Tabel 3. Sumber-sumber pendapatan di SMAN 1 Pelaihari, SMA Negeri 1 Bati-Bati, dan SMA Negeri 1 Jorong Tahun Anggaran 2013/2014.

\begin{tabular}{|l|l|c|c|c|}
\hline No. & \multicolumn{1}{|c|}{ Sumber Dana } & $\begin{array}{c}\text { SMAN 1 } \\
\text { Pelaihari }\end{array}$ & $\begin{array}{c}\text { SMAN 1 Bati- } \\
\text { Bati }\end{array}$ & $\begin{array}{c}\text { SMAN 1 } \\
\text { Jorong }\end{array}$ \\
\hline 1. & Pemerintah (APBN dan APBD) & $\sqrt{ }$ & $\sqrt{ }$ & $\sqrt{ }$ \\
\hline 2. & Usaha Mandiri Sekolah & - & - & - \\
\hline 3. & Orang Tua Sis wa (komite sekolah) & $\sqrt{ }$ & $\sqrt{ }$ & - \\
\hline 4. & Dunia Usaha dan Industri/DUDI & - & - & - \\
\hline 5. & Hibah & - & - & - \\
\hline 6. & Masyarakat Luas & - & - & \\
\hline
\end{tabular}

SMAN 1 Pelaihari berdiri di lingkungan yang sangat strategis yaitu di komplek perkantoran dan padat penduduk. Posisi ini sesungguhnya memiliki daya jual yang cukup menarik untuk ditawarkan kepada user, tetapi pada kenyataannya dari perbandingan dua SMAN 1 Bati-Bati dan SMAN 1 Jorong, partisipasi pembiayaan pendidikan yang berasal dari orang tua siswa masih terlalu kecil. Kecilnya tingkat partisipasi orang tua melalui dana komite diakibatkan adanya kebijakan pemerintah daerah kabupaten tanah laut untuk menyelenggarakan pendidikan gratis. Kebijakan inilah yang menjadi alasan orang tua untuk menolak jika sekolah mengharapkan partisipasi yang lebih besar.

Sebagaimana temuan yang dianalisis sebelumnya bahwa untuk anggaran yang bersumber dari pemerintah daerah yang lebih dominan dan pemerintah pusat melalui BOSSM $75 \%$, sedangkan komite hanya sebagian kecil yaitu 25\%. Prosentase partisipasi dari komite ini terlihat kecil karena cost personal dari siswa tidak ditampilkan, karena tidak didesain untuk diteliti. Berkenaan dengan besaran dan satuan pembiayaan pendidikan secara rata-rata untuk ketiga sekolah masih belum mencapai standar nasional.

Dengan demikian sumber-sumber biaya pendidikan di tiga sekolah ini perlu untuk diusahakan terhadap sumber-sumber selain, pemerintah dan komite sekolah, jika hal ini mengingankan predikat sebagai sekolah unggulan, apalagi sebelumnya pernah menyelenggarakan Sekolah Berstandar Internasional (SBI). Karena apabila ada penataan yang bagus dan mutu keluar yang baik maka sumber-sumber pembiayaan tentu akan didapatkan. 


\section{B. Struktur Anggaran Biaya Pendidikan}

Temuan dalam struktur anggaran pembiayaan pendidikan terdiri dari biaya investasi, personal dan biaya operasi, Biaya personal meliputi biaya pendidikan yang harus dikeluarkan oleh peserta didik untuk bisa mengikuti proses pembelajaran secara teratur dan berkelanjutan. Namun biaya personal ini belum bisa dipaparkan dalam temuan ini. Hal ini di dalam anggaran baik melalui sumber pembiayaan dari pemerintah maupun komite sekolah tidak memuat dalam struktur anggaran dan format anggaran. Karena itu penulis akan memberikan pembahasan pada sudut struktur berdasarkan investasi dan operasi. Terhadap investasi, selama ini dianggarkan melalui Dinas Pendapatan (DPKKA), semua persoalan lahan yang menjadi aset pemerintah daerah selalu melalui Dinas Pendapatan, sehingga pihak sekolah yang akan menambah perluasan tanah bangunan sekolah ini urusan aset pemerintah daerah, karena itu dalam anggaran pembiayaan pada saat penelitian ini sedang dilaksanaan tidak ada.

Bahasan terhadap struktur anggaran yang saat ini dimilliki ini lebih kepada struktur dan susunan anggaran yang bersifat line item (tradisitional), Sebagaimana pernyataan Anggarini dan Puranto (2010:35), hal ini karena terpengaruhnya dari anggaran sebelum adanya anggaran berbasis kinerja. Sedangkan biaya operasi satuan pendidikan meliputi: gaji pendidik dan tenaga kependidikan serta segala tunjangan yang melekat pada gaji; bahan atau peralatan pendidikan habis pakai; dan Biaya operasi pendidikan tak langsung berupa daya, air, jasa telekomunikasi, pemeliharaan sarana dan prasarana, uang lembur, transportasi, konsumsi, pajak, asuransi, dan lain sebagainya. Dari ketiga jenis biaya pendidikan biaya operasi meruapakan biaya satuan pendidikan yang perlu untuk senantiasa menjadi bahan perhatian. Oleh karena itu, kontribusi kelompok di luar pemerintah (pusat maupun daerah) sangat diperlukan untuk menutupi kekurangan biaya operasi agar mutu pendidikan di sekolah semakin meningkat.

\section{Strategi Perencanaan Anggaran Berbasis Kinerja}

Perwujudan tata kelola pemerintahan yang baik yang menganut prinsip partisipasi, transparansi dan akuntabilitas diwujudkanlah sistem anggaran berbasis kinerja. Penerapan anggaran berbasis kinerja juga diharapkan diikuti oleh unit kerja terkecil seperti halnya sekolah. Kepala sekolah sebagai pimpinan manajemen puncak di sekolah memiliki rangkaian kegiatan yang terdiri atas merencanakan, mengorganisasikan, menempatkan staf, memberikan arahan, mengkoordinasikan, dan mengendalikan kegiatan dan staff. Salah satu dalam kegiatan anggaran di sekolah, peran kepala sekolah sebagai penanggung jawab program. Ketepatan manajemen akan mempengaruhi output dan outcome yang akan dicapai. 
Sebagai wujud keterbukaan penentuan program-program yang akan dilaksanakan dalam satu tahun anggaran kedepan disusun bersama seluruh dewan guru, staff, dan komite sekolah dalam wujud RKAS. RKAS merupakan kertas kerja yang berisikan rincian program, besar anggaran beserta sumber dananya (secara rinci terlampir). Dokumen ini disusun oleh tim yang telah ditunjuk oleh kepala sekolah dan penyusunannya mengacu pada visi, misi, tujuan, RKAS dan RKS yang dimiliki oleh sekolah. Hasil wawancara menunjukkan bahwa belum ada standar dalam penyusunan RKAS. Peran komite sekolah dalam penyusunan program di sekolah terlihat berbeda-beda, di SMA Negeri 1 Bati Bati dan SMA 1 Jorong komite sekolah bertidak sebagai pengesah untuk menyetujui anggaran yang telah disusun. Berbeda dengan di SMA Negeri 1 Pelaihari, disekolah tersebut peran komite dalam penyusunan rencana kegiatan sekolah terlihat aktif semenjak membuat draf hingga mengesahkan RKAS. Namun secara keseluruhan RKAS yang telah di sahkan merupakan hasil penjaringan aspirasi dari seluruh elemen di sekolah bahkan pemangku kepentingan dalam hal ini orang tua siswa. Dengan dilibatkannya seluruh pihak, akan membantu sekolah memenuhi tuntutan publik tentang perlunya partisipasi, keterbukaan dan akuntabilitas sehingga dana yang tersedia dapat dibelanjakan secara bijak.

Secara perundang-undangan komite sekolah memiliki peran sebagai peran komite sekolah adalah sebagai lembaga pemberi pertimbangan (advisory agency), pendukung (supporting agency), pengontrol (controlling agency) dan Sebagai penghubung (mediator). Dengan peran penghubung kepada orang tua siswa, anggaran dan besaran iuran komite atau dana partisipasi tersebut dapat terwujud. Dengan demikian strategi pengelolaan anggaran berbasis kinerja yang dilakukan di tiga sekolah ini sudah mendekati sebagaimana yang dikatakan Anggarini Y, dan Puranto B.H, (2012:104) bahwa, prinsip prinsip dalam penyusunan $\mathrm{ABK}$, antara lain; Penekanan pada konsep value for money dan pengawasan atas kinerja output yang diukur dengan beberapa indikator; ekonomis, efesien, dan efektif, 2) Penguatan mekanisme penentuan dan pembuatan prioritas tujuan serta pedekatan sistematik dan rasional dalam pengambilan keputusan, 3) penerapan transparansi, akuntabilitas dan terbukanya bagi partisipasi publik, 4) kegiatan sebagai dasar usulan anggaran bersifat bottom up, 5) pendelegasian wewenang secara wewenang.

\section{Strategi Pelaksanaan Anggaran Biaya Pendidikan}

Setiap penerimaan sekolah yang direncanakan harus terukur secara rasional sehingga dapat dicapai, sedangkan belanja yang dianggarkan merupakan batas tertinggi pengeluaran dan berpedoman pada peraturan perudang-undangan tentang standarisasi harga barang dan jasa. Dalam pelaksanaan anggaran, semua pendapatan dan pengeluaran belanja sekolah harus 
didukung dengan bukti yang lengkap dan sah. Bukti pengeluaran harus mendapat pengesahan oleh bendahara sekolah dan kepala sekolah.

Besarnya dana dari iuran masyarakat yang proses pencairannya mudah dan pertanggungjawabannya hanya kepada komite sekolah, sedangkan dari pemerintah harus melalui SPJ lebih dahulu agak menjadi kendali oleh guru sebagai pelaksana, apabila ada kesulitan atau kendala, maka dana komite sekolah dalam hal pencairan mudah teratasi. Kendala yang dihadapi sekolah biasanya untuk dana-dana yang bersumber dari pemerintah, karena harus melewati proses birokrasi yang panjang sehingga pencairannya dapat terhambat. Keterlambatan pencairan dana dari APBD kabupaten pernah dialami ketiga sekolah.

Sesuai konsep school based manajemen, maka sebenenarnya sekolah telah menerima lebih banyak kebebasan dalam pengambilan keputusan di bidang yang penting seperti kurikulum, staf manajemen dan anggaran, karena adanya otonomi sekolah,. tingkat kebebasan yang diberikan pada sekolah telah membangkitkan permintaan yang besar untuk akuntabilitas di tingkat sekolah dan memantau prosedur yang seharusnya mengizinkan pemerintah pusat untuk menjamin standar kualitas dan kesetaraan di seluruh sistem. Salah satu peran utama sistem pengawasan sekolah adalah untuk memantau mutu pendidikan pada level pengelolaan dan pembelajaran.

\section{E. Strategi Pertanggung Jawaban dan Pelaporan Anggaran Biaya Pendidikan}

Temuan yang ada bahwa untuk pertanggungjawaban dan laporan dana BOS dan BOMM, dari pemerintah pusat dan daerah sesuai dilaksanakan oleh sekolah, hanya saja untuk pertanggungjawaban komite tidak menyertakan bukti-bukti, hal ini menurut penulis dikarnakan belum ada sistem audit internal, karena itu sekolah perlu membentuk tim audit internal. Kelemahan lain pertanggungjawaban sendiri sering tidak dilaksanakan perbulan, khususnya keuangan komite sekolah. Selain itu kewajiban laporan persemester terhadap anggaran baik yang berasal dari pemerintah maupun dari komite sekolah, sehingga sistem keuangan sekolah tidak masalah.

Pertanggungjawaban pembiayaan merupakan proses evaluasi terhadap pencapaian sasaran. Jones (1985:22) mengatakan pertanggungjawaban merupakan peninjauan terhadap transaksi finansial sebagai penjaminan keakuratan, kelengkapan, legalitas dan perbandingan apakah yang dilakukan telah sesuai dengan yang direncanakan. Kegiatan ini terdiri dari pertanggungjawaban penerimaan, penyimpanan, pembayaran, atau penyerahan dana ke pihak-pihak lain yang berhak. Pertanggungjawaban juga dapat berfungsi sebagai pengendalian alokasi dana dan bentuk pertanggungjawaban penggunaan dana. Dalam hal ini 
pengawasan merupakan salah satu proses yang harus dilakukan. Salah satu prinsip yang harus dijalankan adalah prinsip akuntabilitas.

Akuntabilitas merupakan prinsip pertanggung jawaban yang berarti bahwa proses penganggaran dimulai dari perencanaan, penyusunan dan pelaksanaan. Proses tersebut harus dilaporkan dan dipertanggungjawabkan kepada pihak yang memiliki wewenang (pemerintah, orang tua siswa dan guru) sesuai dengan penyusunan pelaporan yang dibuat. Selain itu, masyarakat tidak hanya memiliki hak untuk mengetahui anggaran tersebut tetapi juga berhak untuk menuntut pertanggungjawaban atas rencana ataupun pelaksanaan anggaran (Mardiasmo, 2002 : 104). Dengan adanya akuntabilitas tersebut, bagian administasi dan pihak terkait lainnya akan menjalankan semua program yang sudah direncanakan sesuai dengan prosedur yang ada, serta melaporkan hasil yang sudah dicapai secara transparan kepada masyarakat dan mempertanggungjawabkannya.

Laporan pertanggungjawaban dibuat berdasarkan petunjuk teknis yang telah ditetapkan oleh masing-masing sumber dana. Oleh sebab itu, kepala sekolah harus memastikan bahwa apa yang dilakukan oleh orang-orang yang ditunjuknya dalam pelaksanaan dan pelaporan hasil kegiatan betul-betul sudah mengikuti petunjuk teknis tersebut. Laporan keuangan tidak dalam bentuk LAKIS, karena belum ada Peraturan Bupati maupun Peraturan Walikota yang mewajibkan untuk pelaporan berbasis kinerja. Sistem pelaporan yang masih sederhana, baik yang disampaikan langsung kepada dinas pendidikan maupun komite sekolah (orang tua siswa). Periode penyampaian laporan keuangan berbedabeda masing-masing sumber dana, untuk BOS SM yang dipertanggungjawabkan oleh kepala sekolah dan komite dilaporkan persemester, BOMMDA dipertanggungjawabkan oleh sekolah dilaporkan pertriwulan, iuran komite yang dipertanggungjawabkan oleh komite disampaikan kepada orang tua pada akhir tahun pelajaran. Secara prosedur pertanggungjawaban dan pelaporan yang dilaksanakan ke tiga sekolah sudah berjalan dengan baik, pada hal lain yang adalah mengintegrasikan kedua pelaporan yang terjadi semala ini, yaitu sistem pelaporan terpadu dan efesien dan akuntabel.

\section{F. Faktor-Faktor yang Mendukung dan Menghambat dalam Pelaksanaan Anggaran Biaya Pendidikan Berbasis Kinerja}

Beberapa temuan yang dikaitkan dengan faktor-faktor pendukung dan penghambat pada pelaksanaan anggaran biaya pendidikan berbasis kinerja, sebagaimana berikut ini.

\section{Kekuatan}

a. Semua sekolah yang menjadi objek penelitian mempunyai visi dan misi, tujuan serta sasaran. 
b. Ketiga lembaga satuan pendidikan mempunyai sumber dana yang mencukupi dalam operasional

c. Regulasi pembiayaan dari pemerintah melalui Peraturan Bupati.

d. SDM yang mempunyai kompetensi dan mencukupi untuk melaksanakan kegiatan anggaran berbasis kompetensi

e. Memiliki Sarana prasarana yang lengkap, khususnya dalam pelaksanaan pencairan dana dapat dilaksanakan melalui komputerisasi

\section{Kelemahan}
a. visi tidak terjabarkan secara kuat dalam tujuan, sasaran sehingga dalam anggaran tidak bisa terliat secara jelas pencapaian visi tersebut.
b. Sumber penperimaan dari pemerintah sering terlambat, dan berjalan pada jadual yang berbeda dengan penerimaan dari komite sekolah
c. Kegiatan yang berasal dari sumber pemerintah kurang fleksibel dalam kode kegiatannya sehingga menutup kreativitas dan inovasi yang diberikan melalui DPA Dinas Pendidikan.
d. Bendahara sekolah belum diberikan sebagai bendara pengeluaran yang berdiri sendiri, sehingga tidak memberikan program keuangan melalui SIMDA
e. Sarana prasarana belum terstandar sesuai SPM

3. Peluang
a. Sumber-sumber dari pihak ketiga belum tergali secara optimal untuk menambah sumber pembiayaan sekolah.
b. Melakukan kerjasama seiring dengan tumbuhnya industri dan dunia usaha dalam pemasaran lulusan.
c. Anggaran bisa terlaksana secara optimal apabila dari kedua sumber pembiayaan tersebut dapat diintergrasikan secara terpadu.

4. Ancaman

a. Regulasi pemerintah yang belum tersedia untuk memfasilitasi terhadap kreativitas dan inovasi sekolah, dikarenakan ruang gerak kode kegiatan yang disamakan dengan kegiatan di SKPD, maka cendrung sekolah tidak akan mempunyai prestasi, baik prestasi akadamik, maupun non akademik.
b. Perkembangan lembaga SMA swasta yang berstandar dan lebih berkelas dengan pembiayaan yang tinggi akan lebih diminati.
c. Perkembangan teknologi informasi yang sangat cepat, memerlukan layanan sistem administrasi keuangan yang transparan dan akuntabel.




\section{G. Model Pengelolaan Anggaran Berbasis Kinerja}

Kepala Sekolah dalam analisis data model implementasi pada bab sebelumnya menginginkan anggaran berbasis kinerja yang terpadu, yaitu adanya satu kesatuan dari beberapa sumber pembiayaan pendidikan di sekolah, sehingga mudah menunjukkan pencapaian sasaran kinerja antara masukan dan keluaran. Hal ini dikarenakan masih adanya dualisme dalam perencanaan dan pelaporan, yaitu iuran komite direncanakan bersama-sama dengan orang tua, masyarakat, sedangkan yang dari pemerintah kabupaten/kota pihak sekolah melaksanakan sendiri, komite sekolah hanya berperan pada sisi pengesahan. Hal ini juga berlaku terhadap sistem pelaporannya, maka idealnya model yang diinginkan adalah harus terpadu, dan dapat mengakomodir terhadap kedua sumber tersebut.

\section{KESIMPULAN}

Dari pembahasan strategi pengelolaan anggaran berbasis di SMA Negeri 1 Pelaihari, SMA Negeri 1 Bati-Bati, dan SMA Negeri 1 Jorong, dapat disimpulkan sebagai berikut :

1. Ketiga SMA ini mempunyai karakteristik dan visi dan misi dan berbeda, secara lokasi dan komponen standar pendidikan lainnya sangat mendukung untuk menjadi sekolah unggulan dan berprestasi, namun belum mengintegrasikan visi dan misi ke sistem perencanaan anggaran biaya pendidikan berbasis kinerja, karena ada dualisme sistem penganggaran biaya pendidikan yang dilaksanakan.

2. Mekanisme penganggaran biaya Pendidikan di SMAN 1 Pelaihari, SMA 1 Bati Bati dan dan SMA 1 Jorong dilaksanakan dalam dua bentuk, yaitu sistem anggaran yang berasal dari pemerintah melalui RKAS dengan pendekatan performance budget, yaitu mengutamakan mutu, output serta outcome, sedangkan dari sumber komite, pendekatan tradisional line item budget (LIB) yaitu; lebih kepada permintaan kebutuhan kegiatan dan barang.

3. Struktur anggaran biaya pendidikan berdasarkan temuan di lapangan hanya pada biaya investasi dan biaya operasi, sedangkan biaya personal belum ada.

4. Strategi perencanaan anggaran dilakukan dengan menerapkan prinsip partisipatif, transparan, dan akuntabel, baik internal sekolah maupun komite sekolah. Perencanaan yang berasal dari sumber komite dilakukan secara bottom up, sedangkan dari sumber pemerintah pusat dan daerah secara top down.

5. Strategi pelaksanaan anggaran biaya pendidikan berbasis kinerja, belum murni dapat dilaksanakan, karena persyaratan KPA dan bendahara pengeluaran belum diberikan oleh 
pihak pemerintah, hanya saja melaksanakan anggaran dan format RKAS dana yang diberikan pemerintah daerah masing-masing pada ketiga objek penelitian, sedangkan dana yang bersumber dari komite sekolah dilaksanakan dengan pendekatan berdasarkan format RAPBS/APBS.

6. Strategi penyampaian pertanggung jawaban dan sistem laporan anggaran dilakukan sesuai petunjuk teknis dari masing-masing sumber pembiayaan. Periodisasi pelaporan berbeda-beda seperti yang dilakukan, Untuk dana BOMM, BOS-SM melalui Dinas Pendidikan dilakukan setiap akhir triwulan, dan dana Komite Sekolah di tiga sekolah dilaporkan kepada orang tua siswa tiap akhir tahun pelajaran.

7. Faktor-faktor pendukung dalam pengelolaan anggaran biaya pendidikan berbasis kinerja adalah adanya visi dan misi, ketersediaan sumber keuangan yang cukup besar baik dari pemerintah maupun komite sekolah, adanya bimbingan teknis yang disediakan oleh pemerintah untuk peningkatan kualitas pengelola anggaran di sekolah. Sedangkan faktor penghambatnya adalah belum adanya regulasi kepala sekolah sebagai KPA, dan bendahara pengeluaran berdasarkan SK Bupati.

8. Model implementasi penerapan anggaran berbasis kinerja dapat dilaksanakan dengan mengadopsi sistem penganggaran di perguruan tinggi atau dari pemerintah kabupaten/kota, yakni dengan format RKA/L/K, yang menjadi DPA/DIPA, disertai dengan TOR/KAK, anggaran biaya pendidikan dari komite sekolah dijadikan anggaran yang harus diketahui oleh pemerintah daerah, namun ada kebebasan dan kreativitas penggunaannya oleh kepala sekolah karena termasuk jenis Penerimaan Negara Bukan Pajak (PNBP).

9. Implikasi pengelolaan model pengelolaan anggaran berbasis kinerja adanya memahami dan melaksanakan dari konsep "value for money", yaitu anggaran yang digunakan mempunyai nilai ekonomis, efeisien dan efektif mencapai tujuan dan sasaran dengan target yang telah ditetapkan. 


\section{DAFTAR PUSTAKA}

Anggarini Y, \& Puranto B.H, 2010, Anggaran Berbasis Kinerja, Penyusunan APBD Secara Komprehensif, UPP STIM YKPN.

Ambarita, A. 2013. Kepemimpinan Kepala Sekolah. Bandung: PPS.

Amir. M.T, 2011. Manajamen Strategik Konsep dan Aplikasi. Jakarta. PT. Rajagrafindo Persada.

Anggiriawan, P. B., Wirakusuma, M.G., 2015. Pengaruh Gaya Kepemimpinan dan Budaya Organisasi Terhadap Kinerja Organisasi Dengan Penerapan Good Governance Sebagai Variabel Moderasi. E-Jurnal Akuntansi Universitas Udayana:311-325.

Asmoko, H. 2006. Pengaruh Penganggaran Berbasis Kinerja Terhadap Efektifitas Pengendalian Keuangan. Jurnal Akuntansi Pemerintah Vol.2 No. 2.

Avionita, V. 2013. Pengaruh Implementasi Anggaran Berbasis Kinerja terhadap Kinerja Program Peningkatan Disiplin Aparatur Intansi Pemerintah Daerah (Studi Kasus Pada Badan Perancangan Pembangunan Daerah Kota Bandung). Widyatama.

Bogdan, R.C \& Biklen, S.K. 1982. Qualitative Research for Education: An Intriduction to Theory and Method. United States of America: Allyn and Bacon, Inc.

Bryson, J.M.2003. Perencanaan Strategis Bagi Organisasi Sosial. Yogyakarta. 